\title{
Dworkin's Rights Conception of the Rule of Law in Criminal Law
}

\author{
Should Criminal Law be Extensively Interpreted in Order to \\ Protect Victims' Rights?*
}

\author{
Briain Jansen
}

\section{Introduction}

The rule of law in criminal law is often associated with the idea that statutory provisions of substantive criminal law should ideally be interpreted strictly, that is, strictly in accordance with the ordinary meaning of the legal text and as they were intended by the legislator. ${ }^{1}$ The reasons for interpreting criminal law strictly, in this sense, are well-known. They are associated with legal certainty for the defendant, with democratic legitimacy, and more generally with civilized criminal law. ${ }^{2}$ As a number of scholars have recognized, however, norms of substantive criminal law are regularly interpreted in a way that extends their scope of application. ${ }^{3}$ The European Court of Human Rights (ECtHR) appears to have permitted that kind of extension of the law in adjudication. ${ }^{4}$ In a series of important decisions also known as the marital rape cases, the human rights court ruled that

* I would like to thank Lukas van den Berge, Wibren van der Burg, Andreas Funke, Ferry de Jong, Klaas Rozemond and Sanne Taekema for their suggestions with regard to earlier versions of this article. My thanks also to the VWR and Pauline Westerman for the opportunity to present an earlier version of the argument in this article at a VWR meeting in Groningen, and to the two reviewers for their comments.

1 There may be other ways of defining strict interpretation. In this article I stipulate that 'strict' interpretation is an interpretive approach, which complements a strict textualist method of interpretation, sometimes called grammatical interpretation, with the aim of following the original intentions of the legislator where the textual meaning of the law is uncertain. Compare: Matthias J. Borgers, 'De communicatieve strafrechter. Over de actuele betekenis van het legaliteitsbeginsel in het materiële strafrecht, de beslissingsvrijheid van de rechter en de interactie tussen de wetgever en rechter,' in Controverses rondom legaliteit en legitimatie (Handelingen Nederlandse Juristenvereniging 2011-1) (Deventer: Kluwer, 2011), 119-21; Joost Nan, Het Lex-Certa beginsel (Den Haag: Sdu, 2011), 34, 40-41; Klaas Rozemond, 'Legaliteit in het materiële strafrecht,' $R M$ Themis 4 (1999): 117-19;

2 Andrew Ashworth, Principles of Criminal Law, 6th ed. (Oxford: Oxford University Press, 2009), 69-70; Cesare Beccaria, 'On Crimes and Punishments,' in On Crimes and Punishment and Other Writings, ed. R. Bellamy (Cambridge: Cambridge University Press, 2003), 14-17; Judit G.H. Altena, Het legaliteitsbeginsel en de doorwerking van Europees recht in het Nederlandse materiële strafrecht (Deventer: Wolters Kluwer, 2016).

3 For instance: Marc Loth, 'Op de bres voor rechtszekerheid,' Rechtsfilosofie \& Rechtstheorie 38 (2009): 17-26; Dirk H. de Jong, 'Naar een common law-conceptie van legaliteit,' Delikt en Delinkwent 8 (1999): 687-90; Klaas Rozemond, 'Legaliteit in het materiële strafrecht,' 117-30.

4 Ashworth, Principles of Criminal Law, 63 
a retroactive abandonment of a common law rule of marital immunity for rape in court in order to convict a defendant was not contrary to the rule of law. ${ }^{5}$

Some theorists have accordingly argued that extensive interpretation may sometimes be positively required by the rule of law and the ideal of rights protection in criminal law. ${ }^{6}$ The most well-known representative of this view in the Netherlands is Klaas Rozemond, who follows Ronald Dworkin's distinction between a 'rule-book conception of the rule of law' and a 'rights conception of the rule of law.' ${ }^{7,8}$ According to Rozemond, these conceptions of the rule of law lead to competing methods of interpretation in criminal law. The rule book conception, he argues, is associated with the strict interpretation of the law, as defined above. The rights conception, on the other hand, is associated with its purposive interpretation. Purposive interpretation of the law on the rights conception, Rozemond argues, may require an extension of the scope of criminal law in court in order to protect the rights of victims.

Rozemond's analysis of Dworkin's rights conception provides a well-recognized argument in favour of extensively interpreting criminal law to the detriment of the defendant in the Netherlands. A number of important publications on the rule of law in Dutch criminal law have reviewed its strengths and weaknesses. ${ }^{9}$ Nevertheless, a critical analysis of Rozemond's argument on its own terms, that is, as an argument about 'rights' and Dworkin's 'rights conception of the rule of law' applied to criminal law has, as far as I am aware, been lacking. ${ }^{10}$ In this article I try to fill that gap. I will question whether it indeed follows from the ideal of rights protection in accordance with Dworkin's rights conception of the rule of law, that there may sometimes be an obligation to extensively interpret the law to the detriment of the defendant.

The outline of this article is as follows. In section two, I discuss the rights conception as it is contrasted with the rule-book conception by Dworkin. I then, in section three, lay out Rozemond's application of Dworkin's rule-book conception and rights conception to criminal law. The fourth section formulates a theoretical critique of Rozemond's application of the rights conception to criminal law, which I

5 ECtHR 22 November 1995, no. 20166/92, S.W. v the United Kingdom; ECtHR 22 November 1995, no. 20190/90, C.R. v. the United Kingdom; Ben Juratowitch, Retroactivity and the Common Law (Oxford/Portland, OR: Hart Publishing), 129-130.

6 Tineke P.M. Cleiren, 'Het legaliteitsbeginsel,' in Jurisprudentie Strafrecht Select, ed. C.P.M. Cleiren, Th. de Roos and M.A.H. van de Woude (The Hague: Sdu, 2008), 258-306; Erik Claes, Legaliteit en rechtsvinding in het strafrecht. Een grondslagentheoretische benadering (Leuven: Universitaire Pers Leuven, 2003); Christina Peristeridou, The Principle of Legality in European Criminal Law (Cambridge: Intersentia, 2015); Ashworth discusses what he calls a 'broader purposive approach' in his Principles of Criminal Law, 70. But he does not appear embrace that approach.

7 Rozemond analyses these two conceptions of the rule of law and their implications for criminal law in his 'Legaliteit in het materiële strafrecht.'

8 In this paper I will refer to these conceptions of the rule of law as the 'rule book conception' and the 'rights conception'.

9 For a variety of contributions to that discussion, see the literature cited in footnotes 1, 6 and 9.

10 For two recent discussion of Rozemond's theory from a 'positivist' point of view, see for instance: Judith G.H. Altena, Het legaliteitsbeginsel en de doorwerking van Europees recht in het Nederlandse materiële strafrecht, 46-52; Joost Nan, Het Lex-Certa beginsel, 25-61. 
call 'the objection from criminal law.' Here I discuss a number of reasons for caution with the notion that the ideal of protecting victims' rights mandates the imposition of penal power on a community and the extensive interpretation of criminal law in court. Section five suggests that the rights conception in criminal law is better understood as a negative ideal. Rather than that rights, as such, provide principled reasons to impose penal power on individuals, they provide principled reasons for withholding it. Section six discusses some implications of the rights conception for the principle of legal certainty. I discuss in particular whether the rights conception as a negative ideal implies that uncertainties in substantive criminal law should be resolved in favour of the defendant as a matter of principle. Section seven concludes and summarizes the argument.

\section{The rule-book conception and the rights conception of the rule of law according to Dworkin}

Let us first discuss both the 'rule-book conception' and the 'rights conception' as they are analyzed by Dworkin. ${ }^{11}$ For this purpose, it is important to note that the rule-book conception and the rights conception are coined by Dworkin as contrasting ideals of the rule of law. As such, the rule-book and the rights conception provide competing understandings of what makes a legal order, as a legal order, virtuous. It is from the differences between these two conceptions of the rule of law as ideals for a legal order as a whole, that Dworkin argues that they generate competing theories of adjudication. ${ }^{12}$

As an ideal for a legal order the rule-book conception is relatively straightforward. In Dworkin's words, the rule-book conception requires that 'so far as possible, the power of the state should never be exercised against individual citizens except in accordance with rules explicitly set out in a public rule book available to all. ${ }^{13}$ So formulated, the rule-book conception is primarily the ideal of official compliance with the rule book. Judges may secure that compliance as proverbial watch dogs by imposing the rule book in adjudication. Adjudication in accordance with the rule-book conception of the rule of law, then, is adjudication in accordance with the rule book. But, as Dworkin observes, the meaning of the rule book 'properly understood' may not always be clear. ${ }^{14}$

Dworkin argues that a lawyer who tries to understand the rule book where its meaning is unclear, treats the rule book 'as an attempt at communication and supposes that an unclear rule can be better understood by applying techniques that we use to improve our understanding of other sorts of communication. ${ }^{15}$ Interpreting the law, on the rule-book conception, then, is about understanding

11 Dworkin analyses the 'rule-book conception' and the 'rights conception' of the rule of law in: Ronald M. Dworkin, A Matter of Principle (Oxford: Oxford University Press, 1985), 9-32. 
what the maker of the rule book intended the rule book to mean. ${ }^{16}$ In some cases, when the meaning of the law is unclear, the rule-book conception may therefore require resort to legislative intent in order to clarify its meaning. The meaning of law is then defined, so to speak, by the will of the legislator. The reason for defining the meaning of law in this way, Dworkin argues, lies in a background theory of democracy according to which the exercise of power should ultimately be justified by the will of a democratically elected majority. ${ }^{17}$ This democratic ideal tells unelected judges to abstain from deciding cases on the basis of their own political judgments, and to follow the authoritative requirements of the rule book as they were intended by a democratically elected legislator. ${ }^{18}$

The rights conception, as Dworkin discusses it, is both distinct from the rulebook conception as an ideal for a legal order and as an ideal for adjudication. The basic tenets of the rights conception are described by Dworkin as follows:

'It assumes that citizens have moral rights and duties with respect to one another, and political rights against the state as a whole. It insists that these moral and political rights be recognized in positive law, so that they may be enforced upon the demand of individual citizens through courts or other judicial institutions of the familiar type, so far as this is practicable. ${ }^{19}$

The rights conception, so described, clearly presents a more complex ideal for a legal order than the rule-book conception. As Dworkin puts it, the rule-book conception provides only a single rule of law dimension on which a legal order may fall short: 'It [a legal order] might use its policy power over individual citizens otherwise than as the rule book specifies. ${ }^{20}$ The role of judges on the rule-book conception, as we have seen, is therefore limited to imposing the rule book. Dworkin recognizes the rights conception, on the other hand, to have at least three dimensions of possible failure in the rule of law. Firstly, a legal order may fail on the scope of rights, if it recognizes that citizens have rights, but nevertheless fails to enforce them. Secondly, a legal order may fail in the accuracy of the rights it recognizes, if officials fail to recognize in practice which rights citizens have. And, thirdly, a legal order may lack fairness in the enforcement of the rights, when some citizens have an unfair procedural disadvantage in their access to rights in practice, while these rights are accurately recognized and enforceable in theory. ${ }^{21}$

16 Dworkin, Matter of Principle, 14-16. The idea that the orientation of interpretation on the rulebook conception is to retrieve the intentions of the rule maker, might find further support in Dworkin's discussion on 'interpretation and authors intention' in: Dworkin, Law's Empire, 52-53. For a recent Dutch discussion on the relation between the rule of law, democracy and following legislative intent in Dutch criminal law, see: Borgers, 'Communicatieve strafrechter,' 108-19. For a criticism of the view that interpretation is about retrieving intentions, see: Joseph Raz, 'Interpretation Without Retrieval,' in Law and Interpretation: Essays in Legal Philosophy, ed. Andrei Marmor (Oxford: Oxford University Press, 1995), 155-175.

17 Dworkin, Matter of Principle, 18.

18 Dworkin, Matter of Principle, 13.

19 Dworkin, Matter of Principle, 11.

20 Dworkin, Matter of Principle, 12.

21 Dworkin, Matter of Principle, 12 
Access to rights in adjudication is of particular importance on the rights conception. This access not merely implies that citizens should be able to contest in court the exercise of governmental power against them, for Dworkin points out that '[c]itizens have personal rights to the state's protection as well as personal rights to be free from the state's interference. ${ }^{22}$ An example might be that the state has a duty to protect citizens' contractual rights by giving them access to a court system that is backed up by the coercive apparatus of the state. Dworkin, indeed, goes so far as to say that 'the ultimate question it [the rights conception] asks in a hard case, is the question whether the plaintiff has the moral right to receive, in court, what he or she demands. ${ }^{23}$

It is important to notice that the content of these 'moral' rights that may be claimed in court is not necessarily fixed by the rule book. ${ }^{24}$ Indeed, Dworkin argues that rights follow from the underlying principles and values of the institutional practice of law. ${ }^{25}$ Dworkin argues that we can find out the content of these rights by interpreting the law as an integer participant of law would, that is, by drawing requirements from the law that set the institutional practice of law as a whole 'in its best light.' 26 To be sure, in many cases judges will agree that following the rule book will set the practice of law as a whole in its best light. But the rule book does not, as such, define the content of rights on the rights conception. Characteristic of Dworkin's proposed method of interpretation, is that the interpreter must exercise responsible and principled judgment in order to determine who has a right to win in adjudication. According to Dworkin, sound constructive and principled argumentation will be able to reveal a single right answer to almost all interpretive controversies. ${ }^{27}$ In practice, Dworkin concedes, there is, of course, no guarantee that judges will get it right all the time. The rights that people have in practice, then, will strongly depend on the interpretive decisions judges make in court. ${ }^{28}$ Nevertheless, Dworkin argues that judges are more likely to decide in accordance with rights if they take responsibility for their interpretation of the law, than if they automatically defer to the authoritative decisions of others that are to be found in the rule book. ${ }^{29}$ Principle, 17. See also: Ronald M. Dworkin, Law's Empire (Oxford: Hart Publishing, 1998), 243-44. Dworkin, Law's Empire, 45-86, 243.

Dworkin, Taking Rights Seriously, 132, 151-3, 158; Ronald M. Dworkin, 'Ronald Dworkin Replies,' in Dworkin and his Critics: With Replies by Dworkin, ed. Justine Burley (Malden, MA: Blackwell Publishing, 2004), 288. According to Dworkin 'the right answer thesis (...) 'underwrites' (...) all the arguments I [Dworkin] make about judges' responsibility to pursue legal issues in depth, and citizens' responsibility to pursue these issues for themselves.' 
Dworkin concedes, however, that the idea of constructive and principled interpretation for judges may lead to what he calls an 'objection from democracy'. ${ }^{30}$ According to this objection political judgments about how power should be exercised in a democracy should be made by a democratically elected legislature and not by unelected judges. ${ }^{31}$ This objection fails however, according to Dworkin, if we accept what we might call a 'purposive' conception of democracy. According to such a conception of democracy, the ideal of democracy is intrinsically oriented at respecting the human dignity of legal subjects as individual responsible agents who have a right to rule themselves. ${ }^{32}$ It would lead us beyond the scope of this paper to discuss Dworkin's interpretation of democracy in detail here. Suffice it to say, however, that if we regard democracy as an ideal that stems from the aspiration to protect the equal dignity of citizens as responsible agents as Dworkin recommends, judicial review in order to protect individual rights does not necessarily stand against the democratic ideal. ${ }^{33}$ Indeed, in Dworkin's view, it may then even be required by democracy that judges review legislation in order to ensure that the law respects the equal rights and dignity of citizens.

\section{The rule-book conception and rights conception of the rule of law in criminal law according to Rozemond}

Rozemond's discussion of Dworkin's rule-book conception and rights conception of the rule of law primarily analyzes their implications for adjudication in criminal law. He argues that these two competing conceptions of the rule of law help us explain two competing adjudicative approaches in Dutch criminal law. ${ }^{34}$ As I mentioned in the introduction of this article, Rozemond argues that Dworkin's rule-book conception requires the interpretation of criminal law in accordance with a strict reading of the text and legislative intent. ${ }^{35}$ Rozemond basically incorporates Dworkin's description of what judges would do, if they aim to impose the rule book, properly understood on the rule-book conception, as an attempt at communication by the legislator. ${ }^{36}$ Like Dworkin, Rozemond associates this approach with the democratic ideal which prohibits unelected judges to decide cases on the basis of their own political judgments. In addition, Rozemond argues

30 Dworkin, Matter of Principle, 18-22; Nan, Lex-Certa beginsel, 43-49; Rozemond, 'Legaliteit in het materiële strafrecht,' 119-21.

31 Dworkin, Matter of Principle, 18; see also Ashworth, Principles of Criminal Law, 70.

32 Dworkin discusses his argument for the rights conception of democracy in: Ronald M. Dworkin, Freedom's Law (Cambridge, Mass: Harvard University Press, 1996), 1-38; Ronald M. Dworkin, 'The Partnership Conception of Democracy,' California Law Review 86 (1998): 453-58. Rozemond briefly discusses Dworkin's theory of democracy in 'Legaliteit in het materiële strafrecht,' 120.

33 This is also Rozemond's interpretation of Dworkin's theory of democracy in his 'Legaliteit in het materiële strafrecht,' 120. For a fair criticism of Dworkin's argument for judicial review, see Jeremy Waldron, 'The Core of the Case against Judicial Review,' The Yale Law Journal 115 (2006): 1348-1360.

34 Rozemond, 'Legaliteit in het materiële strafrecht,' 117-19.

35 Rozemond, 'Legaliteit in het materiële strafrecht,' 118.

36 For a recent Dutch discussion on the relation between the rule of law, democracy and following legislative intent in Dutch criminal law, see: Borgers, 'Communicatieve strafrechter,' 108-19. 
that adjudication on the rule-book conception may also be informed by the principle of legal certainty for the defendant and by the ideal of limiting the scope of criminal law. ${ }^{37}$

The rights conception, according to Rozemond, does not require the judiciary to strictly follow the rule book or the intentions of the legislator in criminal law. Rather, he argues, it requires the purposive interpretation of criminal law in order to protect the rights of citizens. An important characteristic of purposive interpretation in criminal law, Rozemond argues, is that it may require an extensive interpretation of the law to the detriment of the defendant in order to protect the rights of victims. In many cases, Rozemond emphasizes in his article, purposively interpreting the requirements of a specific rule of substantive criminal law may yield the same result as strictly following the authority of the rule book or the legislator. ${ }^{38}$ But in hard cases the aim to interpret the law in light of its purpose (to protect the rights of victims) may lead to an extensive reading of a legal text which is contrary to the intentions of the legislator and to the detriment of the defendant. ${ }^{39}$ Indeed, Rozemond believes that in some cases, such as in the case of C.R. v. the United Kingdom, the ideal of protecting victims' rights even requires a departure from the rule book in order to arrive at a reasonable decision. ${ }^{40}$ Rozemond strongly suggests that on the rights conception citizens do not have a right to rely on a strict interpretation of rules in court in order to avoid punishment. ${ }^{41} \mathrm{He}$ argues that, on the rights conception, the defendant in criminal law is not blamed for disobeying 'formal' rules, but is blamed for violating the 'substantive' rights of other citizens. ${ }^{42}$ Rozemond concludes that the law should therefore be interpreted purposively by both citizens and judges, that is, in light of criminal law's aim to protect citizens' rights against crime. ${ }^{43}$

Rozemond supports his argument that criminal law should be interpreted purposively in light of the aim to protect victims' rights with reference to the case law of the ECtHR. ${ }^{44}$ Other scholars too, recognize that ECtHR case law suggests that there is a positive obligation for states to protect the rights of citizens as potential victims of crime. Andrew Ashworth has, for instance, recently summarized the consensus that the ECtHR implies three positive obligations for states to protect the rights of citizens as potential victims of crime:

'i The duty to secure the rights by putting in place effective criminal law provisions, backed up by law enforcement machinery for the prevention, suppression and sanctioning of breaches of such provisions;

Rozemond, 'Legaliteit in het materiële strafrecht,' 118. Note, however, that Dworkin does not believe that adjudication on the rule-book conception is informed by the ideal of legal certainty. See: Dworkin, A Matter of Principle, 16.

38 Rozemond, 'Legaliteit in het materiële strafrecht,' 119.

39 Rozemond, 'Legaliteit in het materiële strafrecht,' 119.

40 Rozemond, 'Legaliteit in het materiële strafrecht,' 130.

41 Rozemond, 'Legaliteit in het materiële strafrecht,' 124-25.

42 Rozemond, 'Legaliteit in het materiële strafrecht,' 125.

43 Rozemond, 'Legaliteit in het materiële strafrecht,' 125.

44 Rozemond, 'Legaliteit in het materiële strafrecht,' 125-29. 
ii The duty, in certain well-defined circumstances, to take preventive operational measures to protect an individual whose right is at risk from the criminal acts of another individual;

iii The duty to have in place effective machinery for investigating complaints of violations of Convention rights, combined with the duty to ensure that there is a thorough and effective investigation capable of leading to the identification and punishment of those responsible. ${ }^{45}$

Rozemond would presumably agree with Ashworth's analysis that the ECtHR may require the imposition of criminal law in order to protect the rights of citizens against crime. But, as was discussed, Rozemond also goes a step further. Rozemond believes that, in addition to the above described duties, there is also an interpretive duty which follows from the ideal of protecting rights. ${ }^{46}$ As was mentioned above, Rozemond believes that the exercise of that interpretive duty to protect rights of citizens as potential victims may sometimes require an extension of the scope of criminal law to the detriment of the defendant. ${ }^{47}$ Thus, Rozemond would add a fourth duty to Ashworth's list:

iv The duty to interpret the criminal law purposively in order to protect the rights of citizens, which may sometimes require an extension of the scope of criminal law. ${ }^{48}$

Rozemond cites the case of C.R. v. the United Kingdom as an example in which the ECtHR appears to have implied that interpreting the law extensively may be mandated in order to protect the rights of citizens as victims. ${ }^{49}$ In this case, the English House of Lords convicted the defendant for rape within marriage, although at the time it was committed a common law rule granting marital immunity for rape would have required an acquittal. ${ }^{50}$ The abandonment of that immunity in court which led to the conviction, gave rise to the question at the ECtHR whether a common law change in criminal law to the detriment of the defendant was in conformity with article 7 (the principle of legality, nullum crimen sine lege) of the convention which prohibits the application of retroactive criminal law. The ECtHR ruled that such a change did not constitute a violation of article 7 , since the abandonment of the marital immunity had been foreseeable and in accordance with the essence of the offence. ${ }^{51}$ In addition, the ECtHR ruled that the conviction for rape within marriage was in conformity with a civilized concept of marriage 'and above all, with the fundamental objectives of the Convention, the very essence of

Andrew Ashworth, Positive Obligations in Criminal Law (Oxford/Portland, OR: Hart Publishing, 2013), 198. The references in the original text have been removed.

46 Rozemond, 'Legaliteit in het materiële strafrecht,' 119.

47 Rozemond, 'Legaliteit in het materiële strafrecht,' 126-27.

48 Rozemond, 'Legaliteit in het materiële strafrecht,' 128-30.

49 Rozemond, 'Legaliteit in het materiële strafrecht,' 127-28.

50 ECtHR 22 November 1995, no. 20166/92, CR v. the United Kingdom. See: Ashworth, Principles of Criminal Law, 63.

51 ECtHR 22 November 1995, no. 20166/92, CR v. the United Kingdom, § 36, 43. 
which is respect for human dignity and human freedom. ${ }^{52}$ Rozemond points out that the extension of criminal law in that case had, then, not been arbitrary and contrary to the rule of law. ${ }^{53}$ But had the extension of the criminal law in court at the detriment of the defendant also been mandated in order to protect (victims') rights?

\section{The objection from criminal law}

It seems to me that there are a number of reasons to doubt that such an extensive interpretation is required by Dworkin's rights conception of the rule of law. In this section I discuss whether the ideal of rights protection indeed mandates the imposition of penal power in order to protect the rights of victims. I will subsequently discuss whether an extensive interpretation of criminal law by judicial review in court (as occurred in the case of C.R. v. the United Kingdom) may be required in light of the ideal of protecting victims' rights.

A first reason to doubt whether the ideal of rights protection requires the penalization of rights violations by citizens, is because it is not immediately clear how doing so serves the aim of protecting victims' rights. ${ }^{54}$ A classical understanding of the function of criminal law would suggest that criminal law protects victims' rights by deterring crime. ${ }^{55}$ Rozemond, accordingly, regards this as the way in which criminal law protects victims' rights. ${ }^{56}$ The ECtHR also appears to hold the view that criminal law contributes to the ideal of rights protection by deterring crime. ${ }^{57}$

One wonders, nevertheless, to what extent the belief that criminal law effectively protects against rights violations between citizens by deterring crime is justified. The question whether criminal law is effective, it appears to me, is an empirical matter and not a matter which we can resolve by considering the importance of rights alone. Those who study the effectivity of criminal law in practice have reached a broad consensus that the authorization and application of punishment does not always have the desired effect of deterring crime in practice. ${ }^{58}$ Indeed, criminal law may variously be less than ideally effective, ineffective, and even

52 ECtHR 22 November 1995, no. 20166/92, CR v. the United Kingdom, § 44.

53 See Rozemond's interpretation of this case, in: 'Legaliteit in het materiële strafrecht,' 129-30.

54 For a discussion of the positive obligations that follow from ECtHR case law: Ashworth, Positive obligations and Criminal law, 196-211.

55 Beccaria, 'On Crimes and Punishments,' 10-11; Herbert L.A. Hart, Punishment and Responsibility: Essays in the Philosophy of law, 2nd ed. (Oxford: Oxford University Press, 2008), 1-28; Dworkin, Taking Rights Seriously, 13-29.

56 Rozemond, 'Legaliteit in het materiële strafrecht,' 123-5.

57 Ashworth, Positive Obligations and Criminal Law, 200-202; ECtHR 26 March 1985, no. 8978/80, X and $Y v$. the Netherlands, §24, 26, 27.

58 Andrew von Hirsch et al., Criminal Deterrence and Sentence Severity: An Analysis of Recent Research (Oxford/Portland, OR: Hart Publishing, 1999); Anthony N. Doob and Cheryl M. Webster, 'Sentence Severity and Crime: Accepting the Null Hypothesis,' Crime and Justice: A Review of Research 30 (2003): 143; Ferry de Jong and Constantijn Kelk, Studieboek materieel strafrecht (Deventer: Kluwer, 2013), 106. 
counterproductive. ${ }^{59}$ To be sure, criminal law may sometimes be effective. But whether this is so, will depend on the circumstances, and there is no reason at all to assume that criminal law, as such, is necessarily suitable, never mind whether it is the most suitable way of protecting the rights of citizens as potential victims of crime. ${ }^{60}$

This leads us to a second reason for caution with the idea that rights violations between citizens should be penalized. Besides the intended goal of criminal law to prevent crime and thereby to protect the rights of citizens as potential victims, it may also yield important undesirable social effects. ${ }^{61}$ The imposition of criminal law in the United States, for instance, leads to mass incarceration with grave consequences for in particular Afro-American communities. ${ }^{62}$ It is interesting to consider that these undesirable effects of criminal law may pose a threat to the individual rights of citizens - on Dworkin's theory of law - to be treated by the state with equal concern and respect. ${ }^{63}$ I submit, therefore, that even criminal law that is effective in protecting citizens against crime is not necessarily mandated in light of the ideal of rights protection.

Whether criminal law should be imposed in order to protect rights, it seems to me, requires a responsible proportionality judgment which takes seriously both the intended and unintended consequences of its imposition that may be reasonably expected in practice. As such, then, the content of criminal law on the rights conception should not merely follow from the aspiration to protect rights of citizens by deterring crime, but also from a considered judgment about its suitability and proportionality as a policy in order to achieve that goal. This characterization of the content of criminal law as at least in part the outcome of a policy judgment, may go some way towards explaining why the ECtHR recognizes 'a margin of appreciation' for states to determine how to 'effectively' protect the rights of citizens by criminal law. ${ }^{64}$ Regarding the choice for criminal law as at least in part a matter of policy instead of purely a matter of rights, may also explain two features of adjudication that may otherwise be more difficult to explain.

A first feature is that in adjudication in criminal law judges do not review whether particular norms of criminal law actually have any deterrent effects on rights violations between citizens in practice, let alone that they engage in a judgment about whether the social benefits and costs of a particular norm of criminal law are proportionate. I at least, am not aware of any such cases. Indeed, it is not very

59 Martin Wright, 'Could a Restorative System of Criminal Justice be more Civilized than a Punitive One,' in Civilizing Criminal Justice. An International Restorative Agenda for Penal Reform eds. David. J. Cornwall, John Blad and Martin Wright (Winchester: Waterside Press, 2013), 388.

60 This point appears to be recognized in: Ashworth, Positive Obligations and Criminal Law, 200-202; ECtHR 26 March 1985, no. 8978/80, X and Yv. the Netherlands, § 24.

61 For an interesting account of these kinds of consequences, see: Council of Economic Advisors (U.S.), Economic Perspectives on Incarceration and the Criminal Justice System (Washington, D.C: Executive Office of the President, Council of Economic Advisors, 2016).

62 Dorothy E. Roberts, 'The Social and Moral Costs of Mass Incarceration for African American Communities,' Stanford Law Review 56 (2004): 1272-1304.

63 For a discussion of the notion of equal concern and respect, see: Ronald M. Dworkin, Sovereign Virtue. The Theory and Practice of Equality (Cambridge, Mass.: Harvard University Press, 2000), 1. 
easy to even imagine how the effectivity of criminal law, and therefore its justifiability in light of the aim to protect victims' rights in practice, should be incorporated into the constructive interpretation of the meaning of a substantive norm of criminal law. Taking the meaning of criminal law, however, as also in part the outcome of a policy decision which aims to achieve the goal of crime deterrence for a whole society without too many other social costs, better appears to fit with the practice of adjudication. That the content of criminal law is in part policy, explains why judges have no obligation and may not even be permitted, on the rights conception, to review its content and bring it into conformity with the ideal situation in which it contributes to the aim of deterring crime. After all, as Dworkin argues, policy decisions properly fall within the scope of the authority of the legislator. ${ }^{65}$ The idea that criminal law is in part a policy decision, then, may explain the lack of review in judicial practice regarding the effectivity and proportionality of criminal law as an instrument that aims to protect the rights of victims by deterring crime.

Secondly, the idea that criminal law represents additionally, albeit in part a policy goal, is also borne out by the fact that there is no individuated political right to have an individual convicted and punished. ${ }^{66}$ It is true, of course, that Dworkin argued that in private litigation, in almost all cases, out of the two competing parties one usually has a right to win. ${ }^{67}$ But this competitive feature of private law is difficult to reconcile with the lack of a constitutional or ECtHR right for victims to have a particular guilty defendant convicted or punished by criminal law. Criminal law, indeed, is characteristically regarded as a form of public law, in which the defendant is held to account to the public for his wrongs; the defendant in criminal law is characteristically not held to account for or to redress the complaints of any particular individual. ${ }^{68}$ In Dworkin's words: 'the geometry of criminal law prosecution (...) does not set opposing rights against one another [and therefore] differs from the rights thesis which holds symmetrically. ${ }^{69}$ In criminal law, Dworkin argues: '[ $t$ ] he accused has a right to a decision in his favour when he is innocent, but the state has no parallel right to a conviction when he is guilty. ${ }^{70}$

\section{The rights conception as a negative ideal}

The ideal of rights protection, then, may not necessarily provide categorical positive reasons for imposing penal power on individuals and a principled community.

68 Malcolm Thorburn, 'Criminal Law as Public Law,' in Philosophical Foundations of Criminal Law, ed. R. Antony Duff and Stuart Green (Oxford: Oxford University Press, 2013); Lindsay Farmer, Making the Modern Criminal Law: Criminalization and Civil Order (Oxford: Oxford University Press, 2016), 66-77.

69 Dworkin, Taking Rights Seriously, 126; Fletcher, Basic Concepts of Criminal Law, 207-208. 
It may, however, often provide strong reasons for withholding the exercise of penal power. This contrast between the role of the rule of law as limiting rather than requiring the exercise of power over individuals is nicely brought out by George Fletcher's distinction between 'negative legality' and 'positive legality. ${ }^{.71}$ The ideal of positive legality holds that there is a 'constitutional duty to punish,' and a reason, as Fletcher puts it, 'to recoil at the thought that an obviously guilty person would walk the streets and the state would do nothing about it. ${ }^{72}$ The rights conception as a positive ideal would require that the state has a positive obligation to prosecute, convict and punish those who commit rights violations in order to protect the rights of victims. ${ }^{73}$ It seems to me that the case for the rights conception as a positive ideal is weak. At the very least, or so I argued, the legislature who aims to enact law in order to protect victims' rights, must qualify his ambitions with considerations of policy. And in court, as we have seen, there are no victims' rights to have a defendant convicted or punished.

The principle of negative legality, on the other hand, does not so much positively mandate the exercise of penal power over individuals, but rather protects individuals against it. It seems to me that the rights conception is better understood as protecting individuals against the exercise of penal power by the state, than as mandating that particular individuals should be convicted and punished. This 'negative' interpretation of the rights conception in criminal law better fits with a classical understanding of individual rights as principled constraints upon the exercise of policy power. Jeremy Waldron, for instance, argues that rights "limit the losses that an individual would have to bear in the pursuit of social policy. ${ }^{.74}$ In a similar vein, Dworkin argues that rights have a special normative force "which trumps over some background justification for political decisions that states a goal for the community as a whole. ${ }^{75}$

If we regard the rights conception in criminal law as a negative ideal which primarily protects citizens against the state, it safeguards against arbitrary coercion in criminal law in at least two ways. The first, is by protecting against penalization of conduct which individuals have a basic right to engage in. It would, then, be contrary to the ideal of rights protection for criminal law to penalize, say, the exercise of specific religious activities that are protected by the ECHR. The judicial review of the law in such situations in accordance with the rights conception, then, may lead a court to declare such a law void, since its very existence threatens the individual rights of citizens under the rule of law. Judicial review of the law on the rights conception as a negative ideal, then, does not lead to extending but to restricting the scope of criminal law in adjudication. ${ }^{76}$

71 Fletcher, Basic Concepts of Criminal Law, 207.

72 Fletcher, Basic Concepts of criminal Law, 207-208.

73 Fletcher, Basic Concepts of criminal Law, 208.

74 Jeremy Waldron, The Law (London/New York: Routledge, 1990), 96 (Waldron's italics).

75 Dworkin, Taking Rights Seriously, 6.

76 Rozemond makes an interesting analysis of what he calls 'restrictive' and 'extensive' teleology elsewhere, in which he seems to recognize this point. See Klaas Rozemond, De methode van het materiële strafrecht (Nijmegen: Ars Aequi Libri, 2006). 
A second way in which the rights conception as a negative ideal protects citizens against arbitrary coercion, is by imposing 'formal' constraints on a legal system. ${ }^{77}$ These constraints are called 'formal' since they pertain to the 'form' the law should take. ${ }^{78}$ Lon Fuller, for instance, famously argued that the rule of law requires law to be general, published, prospective, understandable, consistent with other rules, possible to comply with, stable, and complied with by officials. ${ }^{79}$ The requirement of conformity to 'formal' principles, however, may appear a bit puzzling. Why should 'formal' rule of law principles matter in a rule of law theory which aims to protect the 'substantive' rights of citizens?

One reason may be purely logical. Joseph Raz, for instance, famously argued that if law is to function as law, it must be capable of being obeyed. ${ }^{80}$ Joseph Raz strongly emphasized the logical importance of law's 'form' for the rule of law in order for it to be able to influence the conduct of citizens by guiding it. ${ }^{81}$ Fuller's formal rule of law principles, too, enable law to guide those who are expected to comply with it. It would, for instance, be impossible for citizens to obey retroactive law, uncertain law, law which has never been published, and so on. ${ }^{82}$ Emphasizing the logical value of the formal rule of law principles too much, however, might misleadingly suggest that these principles are only important to the extent that obedience to the law is valued.

But formal rule of law principles are also often valued in the light of citizens' autonomy, because law that is capable of guiding enables them to choose to comply with the law or to at least account for the consequences of not doing so. ${ }^{83}$ For similar reasons, compliance with formal rule of law principles may be associated with respect for human dignity, for, as Raz puts it: '[r] especting human dignity entails treating humans as persons capable of planning and plotting their future. ${ }^{84}$ We should take care to consider, however, that conformity to formal principles of the rule of law does not guarantee a legal system's respect for human dignity. Compliance with these principles may, after all, also make it possible for evil laws to be obeyed. ${ }^{85}$ If one wants to govern with respect for citizens as responsible agents, one may, nevertheless, have a good reason to govern in

Waldron makes a separate case for the existence of what he calls 'procedural principles of the rule of law,' which he distinguishes from both 'formal' and 'substantive rule of law principles.' Principles that Waldron would call 'procedural,' such as the importance of a fair trial, however, are justified according to Dworkin because they follow from the important rights individuals have. See: Dworkin, 'Ronald Dworkin Replies,' 287-88. Waldron, 'The Rule of Law.'

79 Lon Fuller, The Morality of Law, rev. ed. (New Haven/London: Yale University Press, 1969), 39. See also John Finnis, Natural Law and Natural Rights, 2nd ed. (Oxford: Oxford University Press, 2011), 270-73; Raz, The Authority of Law: Essays on Law and Morality (Oxford: Oxford University Press, 1979), 210-33.

80 Raz, Authority of Law, 214.

81 Raz, Authority of Law, 214-19.

82 See also: Matthew H. Kramer, Objectivity and the Rule of Law (Cambridge: Cambridge University Press, 2007).

83 Ashworth, Principles of Criminal Law, 57.

84 Raz, Authority of Law, 221.

85 Raz, Authority of Law, 224. 
accordance with formal rule of law principles. In criminal law this compliance with formal rule of law principles is particularly important, given its orientation towards holding citizens guilty for their actions as responsible agents. ${ }^{86}$

\section{Legal certainty}

The idea, defended above, that the rights conception protects individuals against penal power exercised by the state by providing for certain law that is capable of guiding, may raise the question how we should adjudicate where the law is uncertain. ${ }^{87}$ Some theorists have claimed that the importance of legal certainty as a guarantee for the rights of the citizen as a (potential) defendant implies that the law should be interpreted in favour of the defendant in case of doubt. ${ }^{88}$ Here, I would like to draw attention to two arguments in favour of this claim. The first argument is that a conviction based on uncertain law may be considered 'unfair' to the defendant. The second, is that convictions on the basis of uncertain law may lead to a 'chilling effect,' which causes citizens to abstain from conduct that turns out not to fall within the scope of penal law. Let us discuss both of these arguments in turn.

So why would convicting a defendant in case of uncertainty about the meaning of the law be unfair? A first and perhaps evident possibility, is that the decision to convict may not be based on an 'interpretation' of the law, but on an after the fact 'invention' of new law. ${ }^{89}$ The problem of 'fair decision-making' in court, may then be stated as follows: 'Where a person acts on the apparent meaning of a statute but the court gives it a wider meaning, it is unfair to convict that person because that would amount to retroactive law-making. ${ }^{90}$ That idea seems to be reflected by the jurisprudence of the ECtHR, according to which the non-retroactivity principle in criminal law holds that the law 'should not be extensively construed to an accused's detriment, for instance by analogy. ${ }^{\text {'1 }}$ It may be argued, then, that the right of the defendant not to be subjected to retroactive law-making may make it unfair for the court to construe the law to his detriment in case of doubt.

86 See in general: Hart, Punishment and Responsibility; Ferry de Jong, Daad-Schuld. Bijdrage aan strafrechtelijke handelingsleer voor de normativering van het delictsbestanddeel opzet (The Hague: Boom Juridische uitgevers, 2009).

87 Rozemond, 'Legaliteit in het materiële strafrecht,' 123.

88 The principle that the law should be interpreted favourably to the defendant in case of doubt is sometimes known as the 'principle of strict construction.' See Ashworth, Principles of Criminal Law, 68. Other theorists also recognize this principle, but give it another name. See, for instance, John Rawls, Theory of Justice, orig. ed. (Cambridge, MA /London: Harvard University Pres, 2005), 238; Lon Fuller, Morality of Law, 58; Kramer, Objectivity and the Rule of Law, 120; Marc Loth provides an interesting discussion of this principle, which he refers to as the principle 'in dubio pro libertate,' in 'Op de bres voor rechtszekerheid,' 18-20.

89 For the distinction between 'interpretation' and 'invention' see; Dworkin, Law's Empire, 67-68.

90 Ashworth, Principles of Criminal Law, 68.

91 ECtHR 23 May 1993, no. 14307/88, Kokkinakis v. Greece, § 52. 
That the retroactive application of law is most certainly unfair to a defendant on the rights conception, however, should not have us conclude that all unfair decision-making must be caused by retroactivity. Framing the question in this way would appear to imply that a discussion about fairness is really, properly considered, about the right answer to a question about the meaning of a norm of substantive criminal law. But that appears to lead us into a muddle, since the very problem we are discussing here arises from our ignorance of that right answer. A more fruitful approach to the problem recognizes that the existence of a right answer and the attempt to give it may be insufficient for fair decision-making in accordance with the rule of law. Rather than framing the problem as one about the right answer, we might frame it in terms of whether the answer given should be regarded as an unfair surprise to the defendant. ${ }^{92}$

It is difficult, perhaps even impossible, to give a good general answer to the question when interpretations of the law lead to an unfair surprise. But an attempt at answering that question probably most benefits from a common sense approach. It seems to me fair, then, to expect citizens to be realistic about the possibility of uncertain law and about decision-making in court where the law is uncertain. It should probably not come as a surprise to us that reasonable disagreement about the meaning of the law is possible, and that, in practice, we may be convicted for conduct that is arguably a crime. ${ }^{93}$ In this light, it seems to me that citizens may be expected to account for decisions that, given the scope of actual disagreement in practice, may reasonably be expected in court. ${ }^{94}$ This appears to fit with the case law of the ECHR, which recognizes that an interpretation of the law should not come as a surprise if it can be foreseen if need be with the help of legal advice. ${ }^{95}$ In any case, it is important, in my view, to recognize that whether an interpretation of the law is to be expected in a particular legal system, does not depend on whether one believes it is right.

But there may be another, second, reason - other than that a decision may unfairly surprise a particular defendant - why not to apply the law to the detriment of the defendant in cases of disagreement or doubt about its meaning. That reason is sometimes called the 'chilling effect,' since it holds that the uncertain threat of a sanction may 'chill' behaviour to which the law turns out in court not to apply. ${ }^{96}$ The problem with the chilling effect, then, is the problem of criminal

92 For a discussion of this argument, see for instance: Ashworth, Principles of Criminal Law, 69; Rozemond 'Legaliteit in het materiële strafrecht,' 123; Loth, 'Op de bres voor rechtszekerheid,' 18.

93 Ashworth, Principles of Criminal Law, 63.

94 Jeremy Waldron, 'Vagueness and the Guidance of Action,' in Philosophical Foundations of Language in the Law, eds. Andrei Marmor and Scott Soames (Oxford: Oxford University Press, 2011), 75-79.

95 ECtHR 15 November 1996, no. 17862/91, Cantoni v. France, § 29. 'This requirement is satisfied where the individual can know from the wording of the relevant provision and, if need be, with the assistance of the courts' interpretation of it, what acts and omissions will make him criminally liable.'

Waldron, 'Vagueness and the Guidance of Action,' 75. 
law deterring more conduct than it penalizes. ${ }^{97}$ This effect may be a concern for the rights conception if it leads citizens to refrain from doing what they, properly considered, have a right to do.

One may wonder, however, whether a chilling effect of criminal law is necessarily regrettable in light of the ideal of protecting citizens' rights. A vague norm such as 'no dangerous driving,' for instance, may chill citizens into driving safer than may be absolutely necessary in order to avoid getting caught out by the law. ${ }^{98}$ This apparently unintended effect of the vague norm 'dangerous driving,' is, however, probably not a serious concern to the liberty of citizens. In many other cases too, we may wonder whether citizens are best understood to be at liberty to commit forms of conduct that are arguably a crime.

An interesting observation in this light, made by Waldron, is that chilling may be understood as a form of guidance. At its most basic level, after all, chilling is the effect of citizens taking into account the uncertainty of law in considering what to do. According to Waldron, the chilling effect may even be regarded as a way of respecting human dignity, for, or so he suggests, the uncertainty of law may stimulate citizens to think for themselves what they should do. According to Waldron, this applies to a vague norm such as dangerous driving, which may activate the lingering sense of responsibility within all of us who drive cars. But it may also be said about the possible chilling effect of a vague prohibition of torture. It is not necessarily regrettable, Waldron suggests, that officials responsibly consider for themselves whether they should engage in forms of interrogation that are barely torture, out of fear of being subjected to a penal sanction. ${ }^{99}$

We should, however, also account for the possibility that criminal law works too well, in the sense that it leads citizens who are overly cautious to refrain from exercising their rights out of fear caused by an uncertain threat of punishment. The American Supreme Court, for instance, recognizes the possibly damaging role of the chilling effect on the exercise of the individual right to free speech. The Supreme Court states that 'because the first amendment freedoms need breathing space to survive, government may only regulate in the area with narrow specificity. ${ }^{100}$ So here the chilling effect may provide a reason against vague law. And it may also provide a legitimate and principled reason on the rights conception to decide in favour of the defendant in case of doubt about the meaning of the law. After all, the meaning and the uncertainty of law are as much determined by how it is applied, as by how the legislator drafted it.

\section{Conclusion}

This article investigated whether the rights conception of the rule of law applied to criminal law may sometimes mandate the extensive interpretation of substan-

97 Waldron, 'Vagueness and the Guidance of Action,' 75.

98 Waldron, 'Vagueness and the Guidance of Action,' 76-77.

99 Waldron, 'Vagueness and the Guidance of Action,' 79-81.

100 National Association for the Advancement of Colored People v. Button, 371 US 415 (1963), 433, quoted in Citizens United v. Federal Election Commission, 130 S Ct 876 (210), 892. 
tive criminal law in court in order to protect the rights of victims. The discussion yielded a number of conclusions. It is true, of course, that the rights conception renders the state responsible for protecting the rights of its citizens. And criminal law may have a role in contributing to the realization of that aim by deterring crime. But, or so I argued, we should be cautious not to assume that criminal law is either necessarily effective or proportionate in the costs it imposes on society and individuals. These costs, I suggested, may also be understood in terms of rights. But the empirical considerations involved, strongly suggest that the content of criminal law should be at least qualified by considerations of policy, which should be made by a democratically elected legislature. Regarding criminal law as partially qualified by policy, explains why judges do not review the effectivity of criminal law as a means to protect the rights of victims. It also explains why victims do not have a right to have 'their' defendant convicted and punished. It implies that rights, as such, do not mandate the imposition of penal power in response to rights violations by citizens, or the extensive interpretation of criminal law in court.

Although victims' rights, then, do not in and of themselves provide a positive reason for enacting or extensively interpreting particular penal laws, I argued that rights may nevertheless provide restrictions upon the content of criminal law. The rights conception is therefore perhaps best regarded as a negative ideal; individual rights in criminal law do not positively mandate the imposition of penal power (in legislation or in court), but rather limit the way in which it may be exercised. I subsequently discussed how the rights conception as a negative ideal imposes content restrictions on the law in order to ensure that the state does not penalize the exercise of citizens' rights. At least as important on the rights conception, however, are the formal principles of the rule of law that ensure the law's capacity to guide. Legal certainty, then, is of great importance on the rights conception. But, or so I argued on the basis of an analysis of fairness and the chilling effect, that does not necessarily mean that uncertainties in the meaning of the law in court should be resolved in favour of the defendant. 